\title{
Burkholder, Arno, La red de los espejos. Una historia del diario Excélsior, 1916-1976, México, Fondo de Cultura Económica (FCE), 2016, 187 pp., ISBN: 978-607-16-3720-8
}

\author{
Arnoldo Delgadillo Grajeda*
}

Excélsior es el tercer periódico más antiguo del país, y en la actualidad uno de los más importantes de México. Fue fundado por Rafael Alducin, acompañado en su trinchera por más de 30 periodistas de la época; su primer número circuló el 18 de marzo de 1917. Actualmente pertenece al empresario Olegario Vázquez Raña, es dirigido por Ernesto Rivera Aguilar, y forma parte del Grupo Imagen, que integra también radio, televisión y medios digitales.

No miente su eslogan cuando dice que ha sido "El periódico de la vida nacional”: sus páginas narraron los últimos días de la Revolución Mexicana, el nacimiento de la Constitución, el fin de la época de los caudillos y el surgimiento de un país de instituciones, nunca exento de episodios sangrientos. Excélsior también ha sido, desde sus inicios, una ventana al mundo con su sección de cables internacionales; al tener una red de corresponsales, encabezada en Nueva York por Rodrigo de Llano, pudo dar a conocer de primera mano hechos tan trascendentes como la entrada de Estados Unidos a la Primera Guerra Mundial.

La historia de este periódico ya había sido contada a través de textos personalísimos que rescatan las versiones - como piezas sueltas- de algunos de sus protagonistas, los ejemplos más destacados son Los periodistas de Vicente Leñero, Excélsior y otros temas de comunicación de Miguel Ángel Granados Chapa, Dos poderes de Manuel Acosta Becerra y La terca memoria de Julio Scherer; todos los periodistas, autores de estos libros, mostraron

* Universidad de Colima, correo electrónico: rolandonotas@gmail.com 
fragmentos de la historia de esta publicación desde su mirada, describiendo para la posteridad su paso por Excélsior.

Ahora, en La red de los espejos. Una historia del diario Excélsior, 19161976 se unen las piezas del rompecabezas formando una narración que, con estricto rigor científico, retrata los primeros sesenta años del diario. A diferencia de las obras antes mencionadas, valiosas pero de corte narrativo, Arno Burkholder presenta un texto con técnica historiográfica y una postura profundamente analítica, atendiendo una amplia variedad de fuentes documentales y vivas, brindando contexto amplio de la situación política-social del país en distintos momentos, y entendiendo a la publicación como un objeto de estudio completo y vital.

Metodológicamente es un libro robusto; su autor consultó el archivo de la Cooperativa de Excélsior, resguardado en el Archivo General de la Nación (AGN), donde encontró documentos prácticamente desconocidos hasta ahora; el archivo de la Dirección Federal de Seguridad (también resguardado en el AGN), para comprobar el interés que el servicio secreto tuvo en algunos momentos hacia la Cooperativa Excélsior; el Fideicomiso Archivos Plutarco Elías Calles y Fernando Torreblanca, para integrar la historia del diario durante las décadas de los veinte y treinta; y el Diario de debate de la Cámara de Diputados, para entender qué pensaba la clase política de la publicación en distintas etapas.

También hizo consultas hemerográficas, no sólo a Excélsior, sino a Revista de Revistas, El Universal, Ovaciones, El Sol de México, Siempre! y Proceso. Pero además, Burkholder realizó entrevistas a varias decenas de periodistas, políticos y académicos, como Octavio Colmenares, Regino Díaz Arredondo, Felipe Durán y Miguel Ángel Granados Chapa, quienes lo ayudaron a tener una visión amplia, profunda y multidimensional de esta historia.

El título del libro alude a la relación entre prensa y poder político, como una enorme red hecha de espejos, donde las imágenes son más importantes que la realidad, recordando la afirmación de Jorge Ibargüengoitia de que "los periodistas hablan tanto del poder y están tan en contacto con el poder, que llegan a creer que lo tienen”. Y es que, el eje de análisis de la obra son los que el autor considera los personajes más importantes: la empresa Excélsior (privada y después cooperativa); el periódico Excélsior y otros que también editaba; y el Estado; de tal forma que se evidencian los mecanismos internos del periodismo nacional, a través de las relaciones y fricciones entre estos personajes.

Arno Burkholder de la Rosa es doctor en Historia por el Instituto de Investigaciones Dr. José María Luis Mora y realizó un posdoctorado en la 
Escuela de Graduados en Administración Pública y Política Pública del Instituto Tecnológico y de Estudios Superiores de Monterrey (ITESM). Con artículos publicados en las revistas Historia Mexicana (de El Colegio de México), Secuencia (Instituto Mora), y Boletín del Fideicomiso Archivos Plutarco Elías Calles y Fernando Torreblanca, se ha especializado en la historia de la prensa mexicana durante el siglo XX.

A través de sus 187 páginas, el libro La red de los espejos. Una historia del diario Excélsior, 1916-1976 narra la historia del diario en cinco capítulos (que responden a períodos determinados): en el primero, "El periódico que llegó a la vida nacional”, se habla de su origen (1916-1932), posible gracias a la coyuntura del triunfo de los constitucionalistas y la experiencia laboral de los periodistas de finales del siglo XIX; en el segundo, "Los años de la familia feliz”, se aborda la época dorada de la publicación (1932-1964) que comienza con la creación de una Cooperativa para evitar la desaparición del periódico.

En el tercer capítulo, "Problemas en el paraíso", el autor aborda la crisis que vivió el Excélsior (1962-1968) por los enfrentamientos internos entre los grupos conservador y de apertura al interior de la cooperativa; y en el quinto, en "La memoria, el olvido y el futuro", Arno Burkholder reflexiona sobre la conversión del periódico en una empresa y los retos que enfrentó — permaneciendo como estático y congelado — con la llegada del nuevo milenio.

Mención especial merece el cuarto capítulo, pues además de su solidez, "El Olimpo fracturado"(1968-1976) narra de manera novedosa los hechos que llevaron a la estrepitosa salida del diario de Julio Scherer y su equipo, ante el creciente descontento del Gobierno por la línea editorial del Excélsior; este cambio es uno de los más significativos para la historia del periodismo nacional, por lo que Scherer representa y el hecho de que su exilio haya dado vida a la revista Proceso, marcando un ideario de separación del periodismo hacia el poder público.

El libro es ampliamente recomendado porque se inserta en la corriente teórico-metodológica que ha dejado de ver a la prensa únicamente como fuente para convertirla en el tema de nuevas investigaciones historiográficas, pero además evidencia — con un estudio de caso- que en el periodismo mexicano el juego de poderes sucede entre los intereses empresariales y los del Estado, dejando a la sociedad como simple espectadora y receptora de los reflejos intercalados que interpretan la realidad. Después de conocer el pasado, mirando a futuro la pregunta es: ¿qué necesita México para escapar de esta inmensa red de espejos? 